\title{
Arrangements for Practical Training Through the Example of Ufa State Petroleum Technological University
}

\author{
Lyaysan Zulfarovna Zainagalina \\ Department of Oil and Gas Field Machines and Equipment \\ Ufa State Petroleum Technological University, \\ Branch of the University in the City of Oktyabrsky \\ Oktyabrsky, Russia \\ E-mail: zlz11@mail.ru
}

\begin{abstract}
- the paper is devoted to the description of arrangements for practical training of students majoring in Program Track 21.03.01 Oil and Gas Engineering in Ufa State Petroleum Technological University, Oktyabrsky branch. The paper includes information on objectives, tasks and procedure of the practical training, a list of primary professional skills mastered by the students, including the primary skills and experiences in scientific research in accordance with the Federal State Educational Standard of Higher Education, Generation 3+. Arrangement of the practical training includes visiting leading enterprises of the oil-and-gas industry, training in specialized departments and training at a specialized Scientific Industrial Training Testing Ground SOLUNI. Experience is shared from arrangements for the practical training at the departments of Machinery and Equipment of Oil and Gas Fields and Oilfield Machinery and Equipment. Experience is shared from the work of USPTU branch in Oktyabrskoye, where students completed their practical training within the framework of academic mobility programs in Samara State Technical University, Almetyevsk State Oil Institute, Tyumen State Oil and Gas University. Recommendations are given aimed at improving efficiency of the educational process aimed at primary professional skills and experience.
\end{abstract}

Keywords - practical training, specialized department, professional competences, academic mobility.

\section{INTRODUCTION}

Practical training of students is an integral part of education for Bachelor's degree according to the Federal State Educational Standard of Higher Education (FSES HE), Generation 3+.

The purpose of the practical training is to consolidate theoretical knowledge and provide practical familiarity with the main processes and equipment: in drilling for oil and gas; production of oil and gas, gathering, treatment and transportation of well production; installation, repair and maintenance of oil equipment; provision of students with practical skills and competences in the field of their future professional activity.

Tasks of practical training:

\author{
Flyura Zinnatovna Bulyukova \\ Oil \&Gas Field Machinery and Equipment \\ Ufa State Petroleum Technological University \\ Ufa, Russia \\ E-mail: flura2003@mail.ru
}

- studying organizational structure of an industrial facility (or that of an organization with production facilities), its technological capabilities, manufactured or repaired products, processes in the production cycles, operation of the enterprise;

- studying the current management system;

- familiarizing oneself with the content of main works and research conducted at the facility or in the organization where the practical training is taking place;

mastering approaches, methods and techniques of identification, observation, measurement and control over production, industrial and other processes in accordance with the student's Program Track [1].

The time frame of the practical training is defined by FSES HE in accordance with program tracks, curricula and academic calendar. Referring students to specific practical training facilities is formalized in a form of a university-wide directive. Practical training supervisors are appointed from the numbers of faculty of a graduate chair upon the recommendation of the Head of the Department. On completing the practical training, a student draws a report and takes a graded test.

\section{PRoBlem STATEMENT}

The completion of the practical training shall facilitate mastering general engineering and special subjects' studies during the later years of the university course.

Practical training in obtaining primary professional knowledge and experience, including primary experience in scientific research are among the main subjects for students following the Program Tracks 15.03.02 Process Machinery and Equipment and 21.03.01 Oil and Gas Engineering. The application of innovative educational approaches is necessary in teaching this subject, in order to form deep knowledge, as during their future professional activities graduates will resolve the issues relevant for the whole oil industry, namely:

1 - maintaining a technically sound state of all the oil-field equipment (OFE);

2 - identifying causes of wear and failure of parts, assemblies and units; 
- a skill in modeling process facilities and processes using standard software packages and CAD tools, preparedness to conduct experiments following predefined techniques with subsequent processing and analysis of results

- a capability to participate in calculation and design of parts and assemblies of engineering structures in accordance with design specification and using standard CAD tools

- a skill in application of QA/QC methods to products and objects in the professional sphere, conduct root cause analysis and develop measures for their prevention $[4,12]$.

\section{RESULTS AND DISCUSSION}

The main stage of the practical training of USPTU students includes arrangements for the following: On-site excursions to oil-and-gas industry enterprises; training at specialized department facilities; practical exercises at testing grounds, academic mobility of students within the framework of the practical training. In accordance with the specifics of the Program Track Machinery and Equipment of Oil and Gas Fields, the practical training takes place at oil-and-gas enterprises of various subsectors: PAO ANK Bashneft, Bashneft-dobycha, Polyanskoe LPU MG OOO Gazprom transgaz Ufa, NPP Burintekh, UNPP Soluni.

Deep knowledge in structural materials, analytical mechanics, strength of materials, thermal and thermochemical treatment of metals, metal processing, repair technologies of OFE, polymer materials and practical skills of a future graduate obtained at state-of-the-art oil enterprises will allow training graduates to be capable of solving the most pressing problems of the oil industry. In order to increase the efficiency of the course, a complex approach is used in studying OFE parts and assemblies. The complex approach to studies allows familiarizing the student with all the currently known issues with a given OFE part or assembly with subsequent continuation of the studies with a similar part given for independent study with a reference paper used as a type of reporting.

Taking into account mutual interest in development of cooperation and mutually beneficial relations between institutions of higher education and specialized enterprises, there are specialized departments founded in the USPTU on the foundation of graduate departments. Creation of such specialized departments develops cooperation in training the specialists for higher and post-higher professional education, fundamental and applied research, sci-tech services based on the principles of equal rights and mutual profitability, integration of scientific-intellectual and logistical potentials, while taking into account needs and interests of the parties. There is joint scientific research (research projects and R\&D projects) in the area of improving equipment and processes; joint conferences and workshops are organized; scientific technical developments undergo practical evaluation.

In Ufa State Oil Technical University, a practice has formed for extramural classes in specialized subjects, both practical and lab work-related. Undergraduates from the department of Machinery and Equipment of Oil and Gas Fields have their classes in the subject of Methods and Techniques of Oil and Gas Production and Treatment at the conformance to environmental safety during the works 
2. Preparatory Stage - organizational activity. Compiling, facilities of OOO Bashneft-Dobycha. Master's degree students studying Drill-through Tools study the whole cycle of manufacture of such tools at the facilities of OOO NPP Burintekh. Direct knowledge of modern enterprise organization, technologies and diagnostics of production allow increasing the quality in mastering specialized subjects. Within the framework of the practical training, there are extramural excursions to enterprises of the industry.

One of the key factors for the successful integration of Russian higher education and science into the international educational space is academic mobility, which is on the list of mandatory parameters of the Bologna Process [5]

Academic mobility programs of students may last from one semester to one year, but they may be also oriented towards studying specific subjects or modules in a partner organization, or towards conducting research or undertaking practical training [6].

Objectives of student academic mobility:

- increasing quality of education by means of introducing modern experience of leading Russian and foreign tertiary schools into the academic process;

- increasing marketability of graduates in the Russian and global labor market;

- increasing profile and investment attractiveness of a tertiary school in the global market;

- ensuring educational trajectory of students with consideration for their features and wishes in line with the main curriculum (individualization) [7, 11]

In order to develop student academic mobility, the university needs to solve the following tasks:

- create and develop a grant system for students and instructors;

- improve organizational mechanisms and intra-university regulatory framework of the academic mobility;

- allocate funds to academic mobility and international cooperation in the university budget;

- provide high-quality training of students, instructors and university employees in foreign languages, forming a level of command sufficient for participation in international cooperation programs;

- develop an intra-university system for mobility assessment;

- create infrastructure to support adaptation;

- create social and living conditions for development of academic mentorship;

- develop a system to raise awareness of academic mobility programs $[8,13]$

Stages of implementing the student academic mobility program:

1. Preliminary stage - search for partner universities. approving and signing an agreement (contract) for cooperation between the educational organization and partner organizations (plan of cooperative activities, joint academic mobility program, exchange program, etc.) $[9,14]$.

3. Main Stage - implementation of the agreement. This stage provides compiling and signing of additional agreements, e.g., on creating double degree programs. After that a process of curricula agreement starts, followed with approval of student and instructor arrival terms, legal paperwork for a trip to study in the partner university. After all the necessary documents are complete, students start their studies.

4. Final stage. After completion of the academic mobility program, a student returns to their main university, where credits, subjects and period of studies complete in another universities are transferred to [10].

In Oktyabrsky branch of the USPTU, academic mobility programs covers full-time students in Program Track 21.03.01 Oil and Gas Engineering, educational program Operation of Oil Production Facilities, and program track 15.03.02 Process Machinery and Equipment, educational program Machinery and Equipment of Oil and Gas Fields.

Within the framework of academic mobility, the students of the branch were directed to Samara State Technical University, Tyumen State Oil and Gas University, Almetyevsk State Oil University. Surveying the students who had participated in the academic mobility programs of the Oktyabrsky branch of the USPTU showed that $96 \%$ of surveyed were content with the quality of the student academic mobility program. In the modern context of integrating Russian education into the European educational space, expansion of academic mobility largely defines improvements in efficiency and competitive performance of the Russian educational system.

The assessment tools include achievement indicators for mastering competences that provide that a student:

- can name main goals and objectives in identification of professional and environmental risks in the humanenvironment system that exert a negative influence onto human health and the environment;

- can list the principal diagnostic methods of oil-and-gas equipment;

- can describe the structure and stages of equipment design;

- can name modern software solutions for 3D modeling;

- can describe the principal technologies for each type of works in overhaul and routine repairs of oil-and-gas field equipment;

- determines a relation between physical-chemical and process properties of alloys from their phase diagram;

- knows grades, compositions, main mechanical and process properties of structural materials used in the oil-andgas- industry; 
- shows skills in control of rational and safe professional activity.

The Practical Training Report serves as an assessment tool. It is a product of student's independent work, a brief summary and analysis of results from the practical training in written form. The report includes development of proposals and recommendations aimed at increasing efficiency of operation of the organization.

The work is graded «excellent» if it is complete and its author demonstrates knowledge of methods for obtaining, generalization and systematization of the material in the report at a level of $91-100 \%$.

The work is graded «good» if it is complete and its author demonstrates knowledge of methods for obtaining, generalization and systematization of the material in the report at a level of $61-78 \%$.

The work is graded «satisfactory» if is incomplete and/or its author demonstrates knowledge of methods for obtaining, generalization and systematization of the material in the report at a level below $61 \%$.

The work is graded «satisfactory» if the author has not mastered the instructional material during the practice, does not name the principal components of oil-and-gas equipment, the report lacks structure

\section{CONCLUSION}

During their defense of practical training reports, students in Program Track 21.03.01 Oil and Gas Engineering demonstrated high levels of results in mastering the competences provided by the Federal State Educational Standard.

The arrangement of the practical training for students in Program Track 21.03.01 Oil and Gas Engineering in Ufa State Technical University (USPTU and USPTU branch in Oktyabrsky includes visiting the leading enterprises of the oiland-gas industry, training in specialized departments and at a training testing grounds SOLUNI, student academic mobility, and organically links practical and theoretical training, facilitating development of primary professional skills and experiences, including the primary skills and experiences of scientific research.

\section{References}

[1] N.Alajarmeh, A. Rashed, Learner in the role of instructor: Promoting student peer-collaboration in learning management systems International Journal of Technology Enhanced Learning vol. 11 iss. 2, pp. 121-135, 2019

[2] L.Z Zainagalina, L.V. Petrova, V.A. Petrov, "Analysis of the efficiency of telemetric systems for drilling wells" IOP Conference Series: Materials Science and Engineering. vol. 560, No. 1, Paper no. 012096. December 2018 (MEACS 2018, 2018) DOI: 10.1088/1757899X/560/1/012096. Tomsk. Institute of Electrical and Electronics Engineers Inc.

[3] M.Ya. Khabibullin, L.Z. Samigullina, L.Z. Zainagalina, "Laboratory studies for the momentum of liquid optimal impact on hydrocarbon formation" Advances in Engineering Research (AER) vol. 157. pp. 276279,February 2018 (AIME 2018, 2018)

[4] V.E. Andreev, A.P. Chizhov, Yu.A. Kotenev, Sh.Kh. Sultanov, V.Sh. Mukhametshin, and A.V. Chibisov, "Prediction of Gas Exposure in the

methods for manufacture processes used in production of part and assemblies; 
Atlantis Highlights in Material Sciences and Technology. vol. 1, pp. 727-729 (ISEES 2019, 2019). DOI: 10.2991/isees-19.2019.145.

Colga-Urals," Atlantis Highlights in (ISEES 2019, 2019). DOI: 10.2991/isees-19.2019.132.

[5] R.T. Akhmetov, L.S. Kuleshova, V.V. Mukhametshin, "Absolute Permeability and Distribution of Pore Throats of the Productive Strata of Western Siberia" Atlantis Highlights in Material Sciences and Technology vol. 1, pp. 535-539, June 2019. (ISEES 2019, 2019), DOI: 10.2991/isees-19.2019.105.

[6] R. Paskvan, "Modifying entrepreneurial design by utilising case study analysis". International Journal of Management Practice vol.4 is..4, pp. 392-402, 2011

[7] M. Pogatsnik, "Entrepreneurship in the dual engineering training curricula". Advances in Intelligent Systems and Computing vol. 71b, pp. 679-685, 2018

[8] N.V.Serdyukova, K. Potapov, "Smart interactive system for learning of tax planning". Smart Innovation, Systems and Technologies vol. 99, Pp. 94-103, 2019

[9] R.T. Akhmetov, V.V. Mukhametshin, and L.S. Kuleshova, "Grouping of objects using a limited number of parameters characterizing geological and physical properties of layers," Atlantis Highlights in Material Sciences and Technology vol. 1, pp. 9-13, June 2019. (ISEES 2019, 2019) DOI: 10.2991/isees-19.2019.3.

[10] L.S. Kuleshova and V.V. Mukhametshin, "Estimation of the wells hydrodynamic drag level based on wells geophysical survey data,"
[11] A.Yu.Davydov" Utilization of expert systems for screw pump sets with surface drive management" Advances in Engineering Research (AER) vol. 157. pp. 129-133, February 2018 (AIME 2018, 2018)

[12] L.Z. Samigullina, "Some Aspects of Cognitive and Ideographic Characteristics as a Means of Professional Terminological System Description” European Research Studies Journal..vol. XVIII., iss 4. pp. 197-210, 2015.

[13] R.R. Shangareyev, "Relevance of assessment science research concerning occupational hazards of drilling operations" Ecology, Environment and Conservation Paper.vol. 21. pp. 175-180, 2015.

[14] E.M. Almukhametova, G.F. Shamsutdinova, A.A. Sadvakasov, K.T. Tyncherov, L.V. Petrova, R.R. Stepanova "Modeling development of Fyodorovsky deposit " IOP Conference Series: Materials Science and Engineering. vol. 327. No. 4, pp 042100. December 2017 (MEACS 2017, 2017) DOI: 10.1088/1757-899X/327/4/042100.

[15] M.K. Rogachev, V.V. Mukhametshin, and L.S. Kuleshova, "Improving the efficiency of using resource base of liquid hydrocarbons in Jurassic 711-715, 2019. DOI: 10.31897/PMI.2019.6.711. deposits of Western Siberia," Journal of Mining Institute, vol. 240, pp. 